\title{
SOCIAL CAPITAL AND SCHOOL RESILIENCE FOR DISASTER MITIGATION EDUCATION IN YOGYAKARTA SCHOOLS
}

\author{
Siti Irene Astuti Dwiningrum ${ }^{1}$, Prihastuti ${ }^{2}$, and Suwarjo ${ }^{1}$ \\ ${ }^{1}$ Faculty of Education Yogyakarta State University \\ ${ }^{2}$ Faculty of Psychology Airlangga University \\ email: siti_ireneast@uny.ac.id
}

\begin{abstract}
This study was aimed at determining the usage of social capital to cope with the disaster and school resilience in disaster mitigation education and describing the resilience profiles of the schools in Bantul dan Sleman. The study was qualitative research conducted in high schools located in Sleman and Bantul, Yogyakarta. The subjects were teachers and students. The data were collected using observation, interviews, active participation, FGD, documentation, and questionnaires. The data were analyzed through the stages of data reduction, categorization, interpretation and presentation. Findings show that first, there exists social capital in the form collaboration and social norms between the schools and the society; second, disaster-prone areas need to improve and reform aspects of the school resilience consisting of improvement between the school and the society, establishment of clear rules and consistency in taking them, teaching students life skills, care and support in realizing and communicating high expectations, and providing opportunities for meaningful participation.
\end{abstract}

Keywords: social capital, resilience, disaster mitigation

\section{MODAL SOSIAL DAN RESILIENSI SEKOLAH UNTUK PENDIDIKAN MITIGASI BENCANA DI SEKOLAH DI YOGYAKARTA}

\begin{abstract}
Abstrak
Penelitian ini bertujuan untuk mengetahui modal sosial yang digunakan untuk mengatasi bencana dan ketahanan sekolah untuk pendidikan mitigasi bencana dan menggambarkan profil resiliensi sekolah di wilayah Bantul dan Sleman. Penelitian dilakukan di SMA Negeri di wilayah Sleman dan Bantul di, Yogyakarta. Penelitian ini merupakan penelitian kualitatif. Subjek penelitian adalah guru dan siswa. Pengumpulan data dilakukan melalui observasi, wawancara partisipasi aktif, FGD, dokumentasi dan kuesioner. Data dianalisis melalui beberapa tahapan yakni pereduksian data, kategorisasi, interpretasi dan penyajian. Data dikumpulkan melalui wawancara dan observasi. Hasil penelitian menunjukkan pertama, adanya modal sosial berupa kolaborasi dan norma sosial antara sekolah dan masyarakat; kedua, sekolah di daerah rawan bencana perlu meningkatkan dan reformasi aspek ketahanan sekolah terdiri atas aspek dalam meningkatkan antara sekolah masyarakat, aspek dalam membangun aturan yang jelas dan menjalankan secara konsisten, aspek dalam mengajar keterampilan hidup bagi siswa, peduli dan mendukung aspek dalam mewujudkan harapan dan berkomunikasi diajarkan, dan aspek dalam memberikan kesempatan untuk berpartisipasi.
\end{abstract} Kata kunci: modal sosial, resiliensi, mitigasi bencana 


\section{INTRODUCTION}

Disaster mitigation has not been done optimally because the number of victims is quite big, especially in D.I. Yogyakarta. For example, data shows that earthquake in Bantul and Mount Merapi eruption in 27 Mei 2006 killed more than 5800 people, injured more than 37,000 people, destroyed more than 84,000 houses and damaged more than 200,000 houses. The most damaged areas were Imogiri, Jetis, Pleret, and Piyungan in Bantul; Wedi, Gantiwarno, and Bambanglipuro in Klaten. The victims number is quite big because the social capital role is still insignificant in facing disaster, when the disaster happened or afterwards. Social capital hasn't been considered as an important element in disaster mitigation, even most people haven't understood the elements needed for people in disaster-prone areas in building and strengthening social capital for disaster mitigation, even though, social capital is a collective energy that can be used to take care of disaster mitigation.

Disaster issues are related to the various dimensions of life, both individually and organizationally, so the handling of disasters requires an approach that is comprehensive, so as to build awareness of the disaster requires a socio-cultural approach. While efforts for disaster mitigation approach can be studied from a structural or non-structural dimension, the focus of this research is to study the socio-cultural aspects of the nonstructural mitigation approach.

Disaster management is the science related to the effort to reduce the risk, which includes preparatory actions, support, and rebuilding communities when disasters occur. In general, disaster management is a continuous process that is carried out by individuals, groups, and communities to manage risks in an effort to avoid or reduce the impact of disasters. The action taken depends on the perception of the risk faced. The effectiveness of disaster management relies on the integration of all elements, both governmental and non-governmental. Activities at each hierarchy (individual, group, community) influence on different levels. The disaster management cycle consists of four stages, namely: prevention/ mitigation, preparedness at the stage before the disaster, emergency response, rehabilitation and reconstruction phase after a disaster.

Mitigation is the action taken to reduce the impact caused by the disaster. Mitigation phase focuses on long-term action to reduce disaster risk. Implementation of mitigation strategies can be seen as part of the recovery process if mitigation is done after the disaster. However, despite the implementation of an action recovery efforts, actions taken to eliminate or reduce risk in future be categorized as mitigation measures (Person, cited Dwiningrum 2008, 2012, 2013, 2014). Mitigation measures consists of mitigating structural and non-structural mitigation. Structural mitigation is measured to reduce or avoid possible physical impact of disasters. The examples of structural mitigation measure are the construction of earthquake-resistant housing, infrastructure development, construction of embankments along the river, and so forth. Non-structural mitigation is related to policy measures, development of awareness, knowledge development, public commitment, as well as implementation and operational methods, including participatory mechanisms and the dissemination of information, which is done to reduce the risks related to the impact of disasters. Mitigation measures are the most efficient way to reduce the impact caused by disasters (Dwiningrum, 2014).

Citizen awareness about disaster mitigation is crucial. It is based on the approach in disaster management that one 
principle is the development of human capabilities. The rationale of this study builds upon the approach in disaster management to develop "management capacity", which in principle developed two aspects (Maarif, 2009, pp. 36-37) quoted Dwiningrum (2012, 2013, 2014) namely:

First, Human Resource Capacity. We must admit that the capacity of disaster management in Indonesia still requires to be strengthened. Strengths and resources that exist within the community must be further identified and developed. Cultural values that are rooted within the community must be explored and cultivated as social capital that canenhance the resilience of the people against disaster. By utilizing the advance science and technology, we will be able to strengthenour capacity in handing disaster and the number of disaster events, as well as its impacts can be reduced.

Second, equipment. Series of disaster that occurred simultaneously within last month has become more aware on the importance of available standard equipment that $i$ normally required during sudden-on-set emergency that threaten the lives of thousands of people with vast impacts. The standardequipment that must be owned or at least made availableincludes moderate communication systemand reliable functioning in the affect areas where the regular electricity power and communication line is damaged and transportation means (air, land and sea) available anytime dependable emergency management system.

Social capital is needed for society to be more responsive to the disaster. Social capital is a resource that can be seen as an investment to acquire new resources. The concept of social capital was developed by James Coleman, Pierre Bourdieu discussed further and popularized by Robert Putnam. According to Coleman (1990), on the results of his study on youth and education (youth and schooling), define the concept of social capital as a variant of the entity, comprised of several social structures that facilitate the actions of the perpetrators, whether in the form of personal or corporation in a social structure. Social capital is inherent in the structure of relationships between individuals. The structure of relationships and networks that create a wide range of social obligations, creating a climate of mutual trust, bring the channel information, and establishing norms and social sanctions for its members.

School as formal institution is a source of knowledge about disaster mitigation education. Knowledge of disaster mitigation depends on the approach to "disaster". Broadly speaking, Abdullah (2009, pp. 1221) cited Dwiningrum $(2012,2013,2014)$ states there are three approaches to the problem of "disaster" that is, as a paradigm to understand the phenomenon of disaster as described in Table 1.

Based on the above reasoning can be concluded that the issue of disasters related to various dimensions of life both individually and organizationally, so the handling of disasters requires an approach that is comprehensive, so as to build awareness of the disaster. In this case, the school is very strategic role in providing knowledge about disaster risk reduction. School which is able to develop and contribute to disaster mitigation program is a school that has been able to develop the resilience of the school. School as critical environments are expected to develop students' potential optimally, generate downturn and adjustment to various 
Table 1

Approaches to Disaster Mitigation

\begin{tabular}{|c|c|}
\hline Approach & Focus \\
\hline $\begin{array}{l}\text { Technocratic } \\
\text { Approach to } \\
\text { Disaster }\end{array}$ & $\begin{array}{l}\text { Disaster is seen as phenomena which mainly correlated with nature and } \\
\text { is separated from human's daily experiences as well as common human } \\
\text { activities since disaster is believed to be extra ordinary experience } \\
\text { (Anderskov, 2004, p.10) } \\
\text { The focus toward the power of nature and supernatural asserts an } \\
\text { abnormal condition, unpredictable, unwished, unplanned condition. } \\
\text { (Hewitt, 1983, p.10) }\end{array}$ \\
\hline $\begin{array}{l}\text { Behavioristic } \\
\text { Approach to } \\
\text { Disaster }\end{array}$ & $\begin{array}{l}\text { Disaster in this view is an opportunity as well as the cause of the local } \\
\text { politic of socialization and mobilization and at the same time caused } \\
\text { the alteration in its relationship with state (Oliver-Smith, 1996, p. 309). } \\
\text { Disaster could become a context to from solidarity, activism, new } \\
\text { political agenda and the shaping of new power relation which could } \\
\text { change a power structure. Economic response correlates with the } \\
\text { notion that disaster always destroy the physical environment and } \\
\text { material resources of a community, while causing urgent demand for } \\
\text { material needs }\end{array}$ \\
\hline $\begin{array}{l}\text { The Structural } \\
\text { Dimension of } \\
\text { Disaster }\end{array}$ & $\begin{array}{l}\text { The structural processes that distribute and manage material resources, } \\
\text { wealth power, in a community which meant to be precondition of } \\
\text { disaster. A good structural process would beopen the possibility to } \\
\text { the community to avoid, facing successfully and recover from natural } \\
\text { phenomenon/ challenges (Wisner et al., 2003, p.300). } \\
\text { Here the emphasis is given to the structural processes that distribute } \\
\text { and manage material resources, wealth power, ina community which } \\
\text { meant to be precondition of disaster. A good structural process would } \\
\text { beopen the possibility to the community to avoid, facing successfully } \\
\text { and recover from natural phenomenon/ challenges (Wisner et al., 2003, } \\
\text { p. } 300 \text { ). }\end{array}$ \\
\hline
\end{tabular}

demands of change and the development of social and vocational academic competency necessary to respond to catastrophic events.

By the disaster mitigation, the disaster risk management will be optimized. In addition, the existing disaster mitigation education can improve the performance of disaster management and disaster risk reduction in disaster prone areas. Therefore, disaster risk management needs to be designed to be more creative and proactive by designing the programs of disaster management. It required a paradigm shift in disaster management in Indonesia by changing paradigm in disaster management.

A paradigm shift in disaster management in Indonesia needs to be changed proactively. In this case meant that disaster management is no longer emphasizing the aspects of emergency response, but the overall emphasize on risk management; protection of the public from 
the threat of disaster by the government is a form of protection as the rights of the people, and not merely because the obligation of government; disaster management is no longer solely the responsibility of the government but also the collective affairs of the community, particularly schools. Schools are expected to be a source of knowledge about the disaster that can provide early knowledge of disaster mitigation. However, to construct the paradigm of the disaster as part of the rhythm of life of the Indonesian, people have not run it optimally to take effort to mobilize social energies of the importance of disaster mitigation. The underlying rationale for this study by conducting critical analysis about the knowledge of social capital and school resilience required for disaster mitigation education (Dwiningrum, 2010, 2012, 2014).

This study aims at determining the role of social capital to cope with the disaster and school resilience in disaster mitigation education. School resilience is determined by the condition of individual resilience in the schools (teachers, students, principals). Resilience is the ability to recognize the structure of thought and belief as well as harnessing the power to improve the accuracy and flexibility of thought to regulate emotion and behavior more effectively. This ability can be measured, taught and corrected. Resilience is not determined by how many difficulties that have been passed as a determinant of success or failure in the face of difficult circumstances, but rather is determined by the level of accuracy in consideration of a difficult situation, the number of alternative scenarios we can imagine, the ability to be flexible, and continue to live to grab new opportunities (Sudaryono, 2006, 2007).

Social capital as collective energy is needed to build the schools resilience and the individual resilience. Social capital emphasizes on community togetherness to achieve the purpose of improving the quality of life and continuing to make changes and adjustments continuously especially in responding to disasters. The low level of social resilience influences the school's ability for disaster mitigation. There are many destroyed schools and dead students because of disasters (Shrestha, Yatabe, Bhandary, \& Subedi, 2012, pp. 5265 the purpose of this paper is to analyze cost effectiveness of retrofitting existing buildings in order to make them safer against earthquake and also to add child friendly features. This case study focuses on the simple method of retrofitting on rectangular single storey existing school buildings. The school buildings are of different types, based on material, shape and size, number of storeys and their vulnerability to earthquake is different case by case. The paper also outlines the process of vulnerability assessment and approach to retrofitting. Design/methodology/approach: The paper is based on the data collected from a case study carried out in Aceh (Indonesia; Matsuura \& Shaw, 2015, pp. 613-633; Ophiyandri, Amaratunga, Pathirage, \& Keraminiyage, 2013, pp. 236-249). In the process of change to achieve the goal, the community is always tied to the values and norms as a reference behave, act and behave and relate to others for the purpose of disaster mitigation. Some reference values and the elements that constitute the spirit of social capital among other participatory attitude, an attitude that is caring, giving and receiving, trusting trust, and reinforced by the values and norms that support, in particular to support disaster mitigation.

\section{METHOD}

This study was conducted in a Senior High School located in DIY that are 
located near volcanic eruption (Bantul) and experienced earthquakes (Sleman). Subjects were teachers and students. Data was collected by using observation, interviews, active participation, FGD, documentation and questionnaires. The data were analyzed using the qualitative analysis used to elaborate and interpret qualitative data, especially in tapping social capital owned by the school. The indicators to Measure School Resilience are described in Table 2.
The results of the validity and reliability test of the questions in the instrument (36 questions) show that there were 31 questions which have the value $r>r$ count. A question can be considered as valid when the value of $r$ count which is the value of Corrected Item-Total Correlation > from r-table. Thus, five questions were disqualified from the instrument. After that, the researcher obtained that the Cronbach Alpha value is 0.891 . Coefficient was deemed worthy and sufficient if it achieved the minimum

Tabel 2

Indicators to Measure School Resilience

\begin{tabular}{|c|c|c|}
\hline Aspects & Variables & Indicators of School Resilience \\
\hline \multicolumn{3}{|r|}{ Mitigating risk factors in the environment } \\
\hline 1 & $\begin{array}{l}\text { Increase } \\
\text { bonding }\end{array}$ & $\begin{array}{l}\text { a. Positive organizational culture and mutual support. } \\
\text { b. Togetherness in risk-taking and learning improvement. } \\
\text { c. Clear vision and mission which are communicated and agreed } \\
\text { upon. }\end{array}$ \\
\hline 2 & $\begin{array}{l}\text { Set clear and } \\
\text { consistent } \\
\text { boundaries: }\end{array}$ & $\begin{array}{l}\text { a. Cooperative and mutual support. } \\
\text { b. Sharing to achieve the school goals. } \\
\text { c. Involvement in policies and rules. }\end{array}$ \\
\hline 3 & $\begin{array}{l}\text { Teach life } \\
\text { skills }\end{array}$ & $\begin{array}{l}\text { a. All of the efforts are for the school development. } \\
\text { b. Risk-taking in the individual's skill development. } \\
\text { c. The existence of practical role model. }\end{array}$ \\
\hline \multicolumn{3}{|r|}{ Building resilience in the environment } \\
\hline 4 & $\begin{array}{l}\text { Provide caring } \\
\text { and support }\end{array}$ & $\begin{array}{l}\text { a. All school members have a sense of belonging. } \\
\text { b. Cooperation is enhanced. } \\
\text { c. Give appreciation for every success. } \\
\text { d. Have leaders with good time management. }\end{array}$ \\
\hline 5 & $\begin{array}{l}\text { Set and } \\
\text { communicate } \\
\text { high } \\
\text { expectations }\end{array}$ & $\begin{array}{l}\text { a. The importance of individual's effort. } \\
\text { b. Risk-taking courage. } \\
\text { c. Positive behavior. } \\
\text { d. Individual development is improved and monitored. }\end{array}$ \\
\hline 6 & $\begin{array}{l}\text { Provide } \\
\text { opportunities } \\
\text { for } \\
\text { meaningful } \\
\text { participation }\end{array}$ & $\begin{array}{l}\text { a. The contribution of each member is considered very important. } \\
\text { b. The members grow and learn various strategies and show } \\
\text { mutual respect. } \\
\text { c. Encourage experiments. }\end{array}$ \\
\hline
\end{tabular}


value 0.70 . Given that the Cronbach Alpha value $0.891>0.70$, it can be said that the 31 questions of school resilience can be used for the data collection in the research because they were valid and reliable. Meanwhile, the credibility of qualitative data in the research was obtained by conducting triangulation by cross-checking from various data sources. The instruments were then validated by experts in the subject and in psychometry.

The researcher employed various techniques in collecting the data, i.e. questionnaire, in depth interview, and interview guideline as well as Focused Group Discussion (FGD). Techniques of data analysis used, employed SPSS 17.00 version for Windows in testing the validity and reliability of the instruments.

\section{FINDINGS AND DISCUSSION}

Social capital differs from other popular terms, namely human capital. Everything on human capital refers to the individual dimension, namely power and expertise possessed by an individual. On social capital, it puts more emphasis on the potential of the group and the relationship patterns among individuals within a group and between groups with space attention on social networks, norms, values, and mutual trust which is born of the group members and the norm group. In addition to the main elements forming the shape, there are also other elements of social capital that are no less important. These elements can be said as a condition of adequacy (sufficiency condition) of the form or the awakening of the power of social capital in a community. There are four elements in social modals according to Hasbullah (2006), namely: participation in social networks (participation and social network), exchange of goodness (reciprocity), social norms (social norm), social values, and act proactively (Dwiningrum 2012, 2013, 2014).

Social capital emphasizes the diversity of the community to achieve the purpose of improving the quality of life and continue to make changes and adjustments continuously. In the process of change and efforts to achieve the goal, the community is always tied to the values and norms that guided as a reference behave, act and behave and relate to others. Some reference values and the elements are the spirit of social capital among other participatory attitude, an attitude that is caring, giving and receiving, trusting trust, and reinforced by the values and norms that support them. Another element that plays an important role is the will of the people or groups for continuous proactive, both in maintaining the value, form networks, as well as the creation and the creation of new ideas (Dwiningrum 2012, 2013, 2014). According to Putnam, social capital is formed of trust. Trust agreement itself establish a community through the "norm of reciprocity" and "norms of civic engagement (Häuberer, 2011) quoted Dwiningrum (2013, pp 54-55; 2014).

Social capital is expected to awaken a culture of disaster response which led to the development of social relations in an important problem faced in everyday life. By listening from the opinions of others (learn to learn) students learn to respect the opinions of others and build empathy, in addition to the emergence of new capabilities by comparing himself with another friend in the group (learn to achieve). The process of discussion and dialogue in the social process is expected to build awareness of personal change student, so that they feel there is something that is melting from inside their feeling that needs and requires others positively (learn to growth) and in turn all will proceed 
towards the more developed the perspective of others to see a problem, be aware of the needs of social skills in interacting with other people especially in crisis situations (learn to cooperative), jointly important as excellence in problem solving together.

Results of research trying to dig about students' knowledge of social capital is very attractive for observed and analyzed further, because the concept of social capital tends to be not understood by the public. These results indicate that both the students from the high school Bantul (53\%) and high school Sleman $(27 \%)$ answered "know" the concept of social capital, but not all of them respond to the true meaning of social capital, while others are immediately answered "do not know" what it is social capital. This phenomenon proves that the concept of social capital has not been popular with students, as well as in the environment. Students who answered do not know the meaning of social capital, even just heard the word of social capital, while the students who answered "know" because never heard that term and try to interpret it according to their prior knowledge. Based on the analysis of answers of students who live in the district of Bantul DIY states that social capital is a pattern of life associated with social values required to interact and cooperate in society.

Social capital is also interpreted as a concept associated with the study of social networks. While students who live in the district of Sleman DIY, social capital is the capital required to live in a social environment to build a social network. Social capital is a person's ability to socialize with the environment for a particular purpose. Conclusion of the students' answers proved that knowledge of social capital is still very necessary, so that social capital actually assessed as public capital inherent in the structure of society that can be used to improve the quality of life. Related to the purpose of this study, the social capital that is owned by the school apparently has not been used optimally, whereas in disaster mitigation is an important aspect of social capital needed to build disaster response and disaster mitigation (Dwiningrum, 2015).

Social capital starts to become interesting study, because social capital is a resource that can be seen as an investment to acquire new resources. Dimension of social capital is quite broad and complex. On social capital is more emphasis on the potential of the group and the relationship patterns among individuals within a group and between groups with space attention on social networks, norms, values, and mutual trust which is born of the group members and the norm group. Social reality illustrates that social capital has not been understood by the students as something inherent in the structure of relationships between individuals. The structure of relationships and networks that create a wide range of social obligations, creating a climate of mutual trust, bring the channel information, and establish norms and social sanctions for its members. Even some of students do not realize that in any relationship or social relations cannot be separated from the role of social capital. Social capital is needed to build social relationships, present 'aggregate resource potential, and proprietary networks that last long in the school structure is not recognized by the school community (Dwiningrum, 2015).

Nevertheless, the results of this study also proves that the ignorance of the meaning of social capital is not always interpreted in the action, therefore cognitive knowledge is not always synonymous with "action or behavior". It is proved that 
although students do not know the meaning of social capital but the student has applying the elements associated with social capital when a disaster occurs. Of the actions of students tend to do during and after a disaster occurs such as: to save themselves, help families or neighbors, as well as when asked how to build trust and cooperation in the event of a disaster. In addition, students are able to explain the importance of establishing a good relationship, be kind, honest, maintain communication, mutual respect and help each other when disaster or disaster (Dwiningrum, 2015).

Based on the diversity of the students' answers can be interpreted that the students have the social capital in interacting with friends, family, and those around the neighborhood. Therefore, social capital of the students also indicates that high school students in disaster-prone areas has been understanding of values and social norms but not yet realized it as a part of social capital that can be used as a social energy to be able to conduct disaster mitigation more optimal times of disasters. As a consequence, disaster mitigation measures have not become a social activity in case together, but still individualized, limited to the family environment. Similarly, if it is associated with school activities based on social capital,it is not optimal in responding during disaster and postdisaster.

With the two elements of social capital possessed by the students' cooperation and social norms of the education-based mitigation of social capital can be optimized. This is supported by the opinion of the majority of the students that cooperation is an important thing that is needed in social life. By strengthening the social capital that has been owned by the school can be used for educational purposes disaster mitigation. The students, who generally live in areas prone to disasters and never faced catastrophic events, generally have a number of actions to overcome the disaster with the attitude and behavior that aims to prepare for and respond to disasters, and trying to save from the sacrifice of disasters and helping the victims. Some examples were performed by the students when a disaster occurs between are: save yourself, family, save the family, save yourself and belongings to a safer place, seek proper shelter, help others, pray, seek immediate family, searching for evacuation routes, evacuate and assist people affected by the disaster, run and find a safe place together.

Resilience is the ability to recognize the structure of thought and belief as well as harnessing the power to improve the accuracy and flexibility of thought to regulate emotion and behavior more effectively. This ability can be measured, taught and corrected. Resilience is not determined by how many difficulties that have been passed as a determinant of success or failure in the face of difficult circumstances, but rather is determined by: the level of accuracy in consideration of a difficult situation; the number of alternative scenarios we can imagine; the ability to be flexible; continue to seize the opportunity of new life (Dwinigrum, 2012, 2013). Resilience is an individual's ability to revive and adapt to a disaster's effects. Measuring resilience of disasters now becomes a study that gains more attention from researchers (Arbon, Steenkamp, Cornell, Cusack, \& Gebbie, 2016, pp. 201215). The efforts to understand resilience cannot be separated from two factors, i.e. protective factor and risk factor (Barankin \& Khanlou, 2009, in Dewi \& Hendriani, 2014, pp. 37-38).

School as critical environment is expected to develop students' potential 
optimally, generate downturn and adjustment to various demands of change and the development of social and vocational academic competency. This is in line with the statement of Ririkin and Hoopman (Handerson 2003, quoted Dwiningrum 2012, 2013):

"Resilience can be defined as the capacity topping back, rebound, successfully adapt in the face of adversity, and develop social, and academic, and vocational, competence despite exposure to service stress or simply to the stress that is inherent in today's world".

If it is associated with the above definition there is no one need to develop resilience in order to continue to exist and adapt to the demands of social change. Everyone has different capabilities in developing aspects of resilience, however, the school can actually be used as a medium to develop the resilience of students and teachers who are needed to deal with the changes. Teachers have a direct role in developing students' potential. The involvement of teachers in improving the quality of a school is determined by many aspects. Analysis of the participation of teachers have been linked to the process of building a school risiliensi. In building the resilience of schools, teachers have an important role to drive all aspects, as described as Figure 1.

By understanding the above image can be assumed that in increasing the resilience of the school at the end of the step is determined by the aspect of participation. In detail, school resiliency is the process through which the school through various stages as follows (Dwiningrum 2012, 2014): improve ties with schools, clarity of rules, teaches "life skills", care and support, communicate and realize the hope, the chance to participate.

According to data analysis related to six aspects of school resilience can be described in Table 3.

School resilience profile in Bantul and Sleman is explained in Figure 2 and Figure 3.

Figure 1. The Resiliency Wheel

$B$ - Build R esiliency in the Environment: 4,5,6

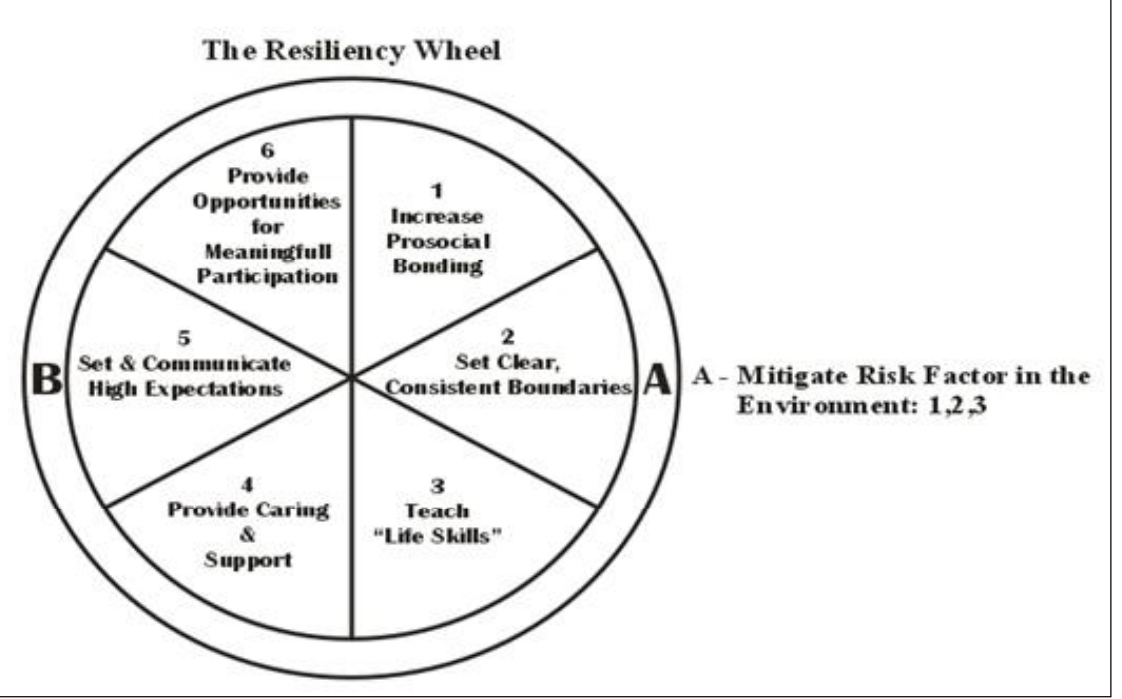


Tabel 3

The Profile of School Resilience

\begin{tabular}{|c|c|c|c|c|c|c|c|c|}
\hline \multirow{2}{*}{ School Resilience Aspects } & \multicolumn{4}{|c|}{ BANTUL } & \multicolumn{4}{|c|}{ SLEMAN } \\
\hline & 4 & 3 & 2 & 1 & 4 & 3 & 2 & 1 \\
\hline & \multicolumn{8}{|c|}{ Mitigating risk factors in the environment (\%) } \\
\hline 1. Increase bonding & 23 & 23.1 & 36.1 & 7.22 & 23.1 & 28.6 & 38.5 & 9.9 \\
\hline $\begin{array}{l}\text { 2. Set clear and consistent } \\
\text { boundaries }\end{array}$ & 19 & 50.5 & 16.5 & 14.4 & 23.1 & 37.4 & 31.9 & 7.7 \\
\hline \multirow[t]{2}{*}{ 3. Teach life skills } & 21 & 40.2 & 25.8 & 13.4 & 18.7 & 47.3 & 23.1 & 10.9 \\
\hline & \multicolumn{8}{|c|}{ Building resilience in the environment (\%) } \\
\hline 4. Provide caring and support & 19 & 40.2 & 35.1 & 6.2 & 17.6 & 41.8 & 29.7 & 11 \\
\hline $\begin{array}{l}\text { 5. Set and communicate high } \\
\text { expectations }\end{array}$ & 25 & 36.1 & 25.8 & 13.4 & 13.2 & 57.1 & 16.5 & 13.2 \\
\hline $\begin{array}{l}\text { 6. Provide opportunities for } \\
\text { meaningful participation }\end{array}$ & 28 & 28.9 & 32 & 11.3 & 17.6 & 47.3 & 28.6 & 6.6 \\
\hline
\end{tabular}

Figure 2. Mitigating Risk Factors in The Environment (\%)

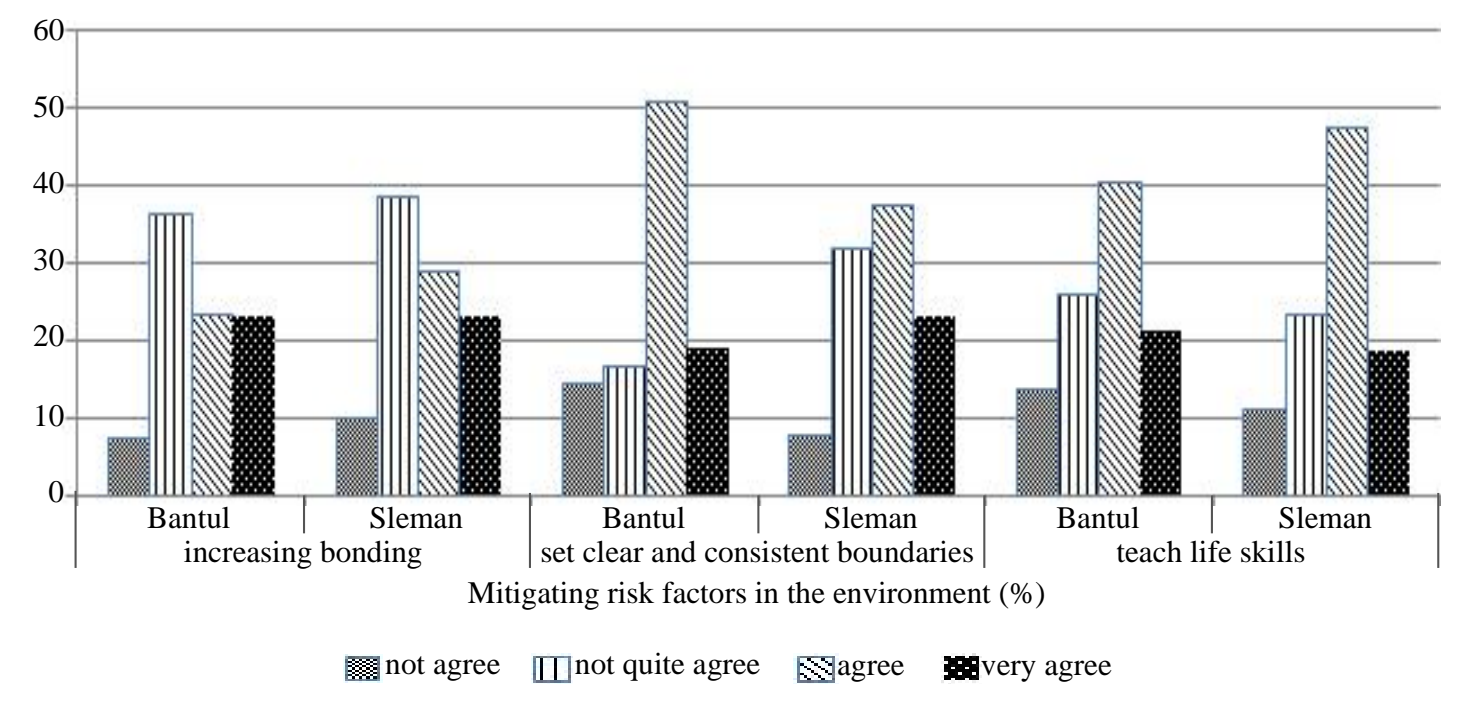

Based on data of two figures above, it can be concluded that:

First, increase bonding. Based on the Table 3, it can be concluded that the majority of high school students as much as $39.1 \%$ Bantul, Sleman as many as 38.5
$\%$ with a ratio of 39:38, explaining schools in Yogyakarta (Bantul and Sleman) has not been able to function in terms of increasing bonding with the school, setting clear rules and consistent, teach life skills, care and support, realize and communicate high 


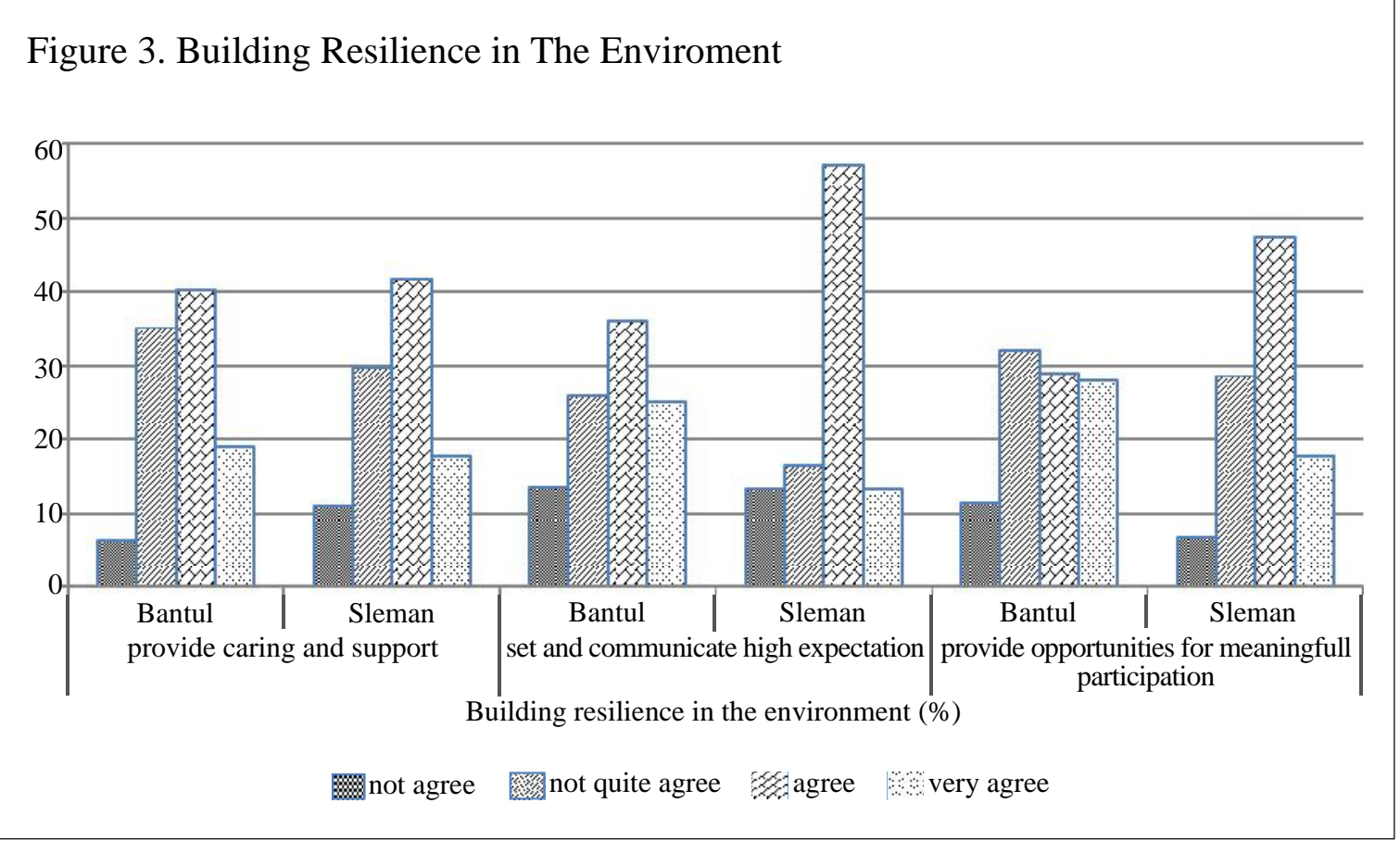

expectations, providing an opportunity to participate. The social reality proves that resilience schools tends to be not strong, because it has not reached more than $50 \%$, which means that schools have not been able to play an optimal role at a critical time in the face of disaster. As a consequence, schools did not play an optimal role in building a culture of disaster awareness and disaster response, disaster mitigation role assumed that tends to be not maximized. Therefore, the above data can be used as a recommendation to the school in order to improve the resilience of the school, because the school resilient assumed it would be easier to mitigate disasters.

Second, set clear and consistent boundaries. Based on the Table 3 can be concluded that the data processing on information obtained through the aspects of resilience schools set clear rules and consistent by high school students each district, it is known that the majority of high school students Bantul region (50.5\%), Sleman $(37.4 \%)$, with a ratio of $50: 37$ is at quite appropriate category. It describes the school has been able to establish a clear and consistent rules implemented in the school environment. But looking at the statement with the percentage of students who are still under $50 \%$ clearly shows that the school has not been able to establish clear rules and implement them consistently. Results of interviews obtained explain most of the school community (students and teachers) do not understand how the behavior expected by the school and comply with regulatory support, students also explained that the schools do not have the means in the form of a team that cares about the problems of students, a discussion related to the norm, rule, the expected goals of school community rarely even not work as expected.

Third, teach life skills. The data in Table 3 shows that the majority of high 
school students who live in disaster-prone areas to inform the resilience of schools based on the dominant aspect of life skills taught in categories quite appropriate. A total of $40.2 \%$ of students Bantul, Sleman region $47.3 \%$ of students with a ratio of $40.5 \%$, the school has been able to explain in this case the teacher life skills for the citizens of the school. Quantitative information indicated through percentage is still below $50 \%$ informed schools in the three regions, unresolved teach life skills for students. Based on the results of interviews captured via high school students obtained information that most students do not yet have and use the ability to behave assertively, healthy conflict resolution, decision making, problem solving, and the ability to manage stress.

Fourth, provide caring and support. Based on the Table 3, it can be informed that the resilience of the school through the aspects of care and support high school students in DIY is (Sleman and Bantul) dominant in quite appropriate category. Informed that the school (the school community) have been able to actualize the attitude of caring and support among the school community. It can be seen in the diagram above as much as $40.2 \%$ of high school students Bantul, Sleman 41.8 $\%$ of high school students and a ratio of 40:41 shows that schools have been able to actualize awareness and support among the school community. The percentage of students still at the limit of less than $50 \%$ indicates that the attitude of care and support that occurs not in line with expectations. Based on the results of interviews with the majority of high school students explained that the school community (students and teachers) still feel not cared for, supported, even to gain recognition or awards. It is suspected the school is still too focused on the rules of the center.
Fifth, set and communicate high expectations. Based on the Table 3 data obtained mostly high school students in DIY disaster-prone regions (Sleman and Bantul) explain the resilience of the school as seen from the aspect of the realization and hope taught tell more dominant in quite appropriate category. A total of $36.1 \%$ of high school students Bantul region, 57.1\% of high school students Sleman ratio 36: 57 explain that schools have been able to play a role in realizing and communicating expectations are taught in the school community, especially students. The percentage is still below $50 \%$ clearly shows that expectations are taught to students has not communicated and realized well. This is supported by data from interviews indicating that the discovery of high school students still pessimistic, do not have confidence in the future success, teacher or student who gave a negative label on the students.

Sixth, provide opportunities for meaningful participation, the data in Table 3 informs that most high school students proneness to explain the resilience of the school through the aspects of the opportunity to participate in the category is quite appropriate. Informed as much as $28.9 \%$ of high school students Bantul, Sleman $47.3 \%$ students and the ratio of 29:47, explains the school has been able to implement and actualize the school community an opportunity to participate in school improvement. Quantitative data that has not reached $50 \%$ indicate that schools in the region which is a disaster-prone area has not fully implemented a policy to provide the opportunity to participate in the school environment. Based on interviews, the information obtained high school students have not been involved in various programs that emphasize student services, school, and community. Students 
explained that they are rarely involved in school decision-making process, including the determination of the rules.

Based on the above, it can be concluded that the high schools in DIY especially in Bantul and Sleman as disaster-prone areas need to improve and to reform aspects of resilience schools consisting of aspects in improving relationships between the school community, the aspect in establishing clear rules and run consistently, aspects in teaching life skills for students, care and support aspects, aspects in realizing and communicating expectations are taught, and aspect in providing an opportunity to participate. Based on the results of research on school resilience excavated using a questionnaire can be broadly described as Figure 4.

Based on the above diagram can be informed that the majority of high school students as much as $39.18 \%$ Bantul, Sleman as many as $41.76 \%$ with a ratio of $39: 42$, explain schools in Yogyakarta (Bantul and Sleman) has not been able to function in terms of improving ties with the school, setting clear rules and consistent, teach life skills, care and support, realize and communicate high expectations, providing an opportunity to participate. The social reality proves that resilience schools tend to be not strong, because it has not reached more than $50 \%$, which means that schools have not been able to play an optimal role at a critical time in the face of disaster. As a consequence, schools did not play an optimal role in building a culture of disaster awareness and disaster response, disaster mitigation role assumed that tend not maximized done. Therefore, the above data can be used as a recommendation to the school in order to improve the resilience of the school, because the school resilient assumed it would be easier to mitigate disasters.

Figure 4. Diagram of the School Resilience Recapitulation of Senior High School Students in DIY Disaster Prone Area

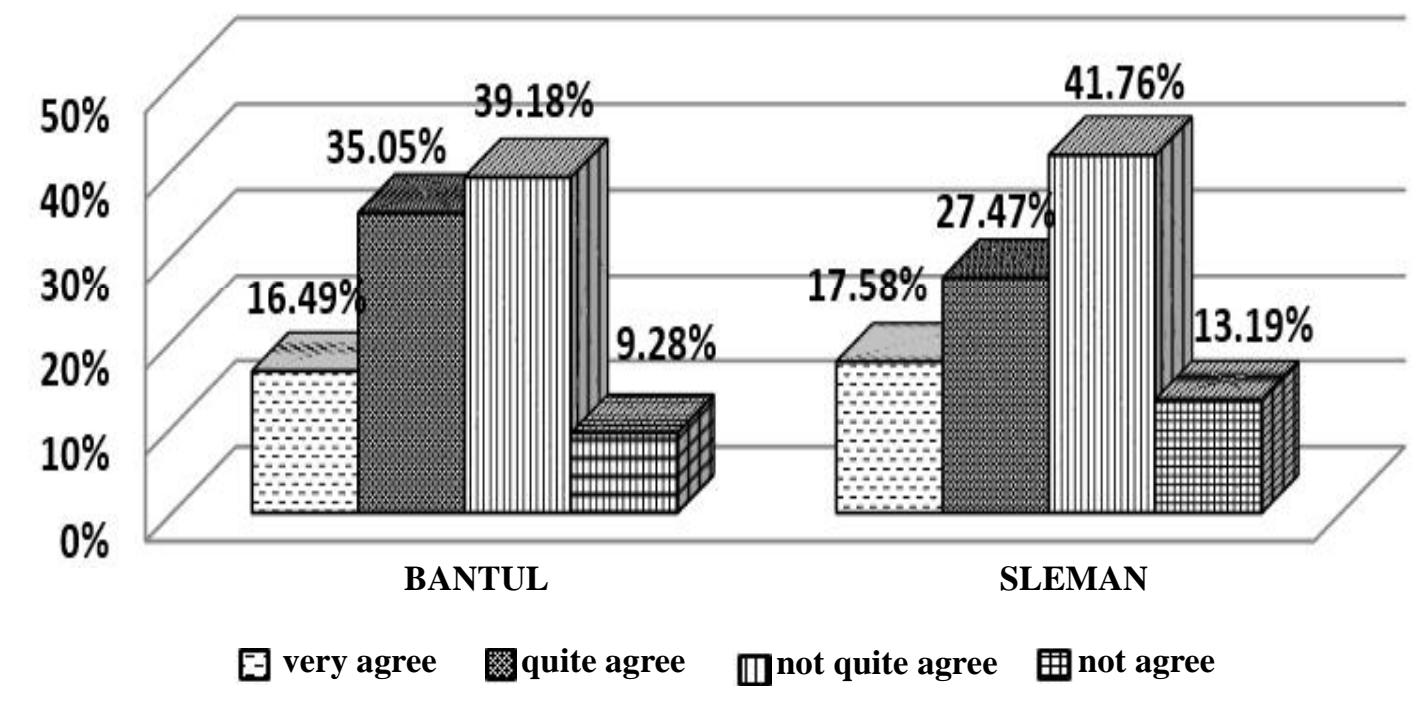




\section{CONCLUSION}

Results of this study concluded that the majority of students do not know the meaning of social capital, so that the students' knowledge of social capital is not optimal. As a consequence of social capital is not yet understood, it is used as a social energy that exist within a social structure that is required for disaster mitigation. Based on the research, that disaster mitigation education by utilizing social capital will be easy to do, because students are already using social capital elements that values and social norms and cooperation to mitigate the disaster before and after the disaster. The picture of the resilience of the school in general is already owned by the school but tend not optimal. Given the resilience of school social capital can be strengthened so thatrole in disaster mitigation education more efective.

Based on the results of the study recommended that the concept of social capital needs to be socialized at school, so the school can strengthen the role of social capital in improving the quality of schools, especially in the face of disaster can be used as a medium for education on disaster mitigation. With the strengthening of social capital is expected resilience stronger schools, so the schools more involved in education disaster mitigation.

\section{REFERENCES}

Arbon, P., Steenkamp, M., Cornell, V., Cusack, L., \& Gebbie, K. (2016). Measuring disaster resilience in communities and households. International Journal of Disaster Resilience in the Built Environment, 7(2), 201-215. doi: 10.1108/ IJDRBE-03-2015-0008.

Coleman, J. C. (1990). Foundations of social theory. Cambridge: Harvard University Press.
Dewi, N. R., \& Hendriani, W. (2014). Faktor protektif untuk mencapai resiliensi pada remaja setelah perceraian orang tua. Jurnal Psikologi Kepribadian dan Sosial, 3(3), 37-43.

Dwiningrum, S. I. A. (2008). Pemulihan psikologi-sosial pasca gempa oleh guru di Kabupaten Bantul DIY. Cakrawala Pendidikan, 2(2), 201-213.

Dwiningrum, S. I. A. (2010). Peran sekolah dalam pembelajaran mitigasi bencana. Jurnal Dialog Penanggulangan Bencana, 1(1), 30-42.

Dwiningrum, S. I. A. (2011). Desentralisasi dan partisipasi masyarakat dalam pendidikan. Yogyakarta: Pustaka Pelajar.

Dwiningrum, S. I. A. (2012). Ide pengembangan modal sosial untuk peningkatan mutu sekolah pasca erupsi Merapi (Studi Kasus di SD Negeri Umbulharjo, Kabupaten Sleman Yogyakarta, Indonesia) (Laporan penelitian). Fakultas Ilmu Pendidikan UNY, Yogyakarta.

Dwiningrum, S. I. A.(2013). Nations character education based on the social capital theory. Asean Social Science, 9(12), 144-155.

Dwiningrum, S. I. A. (2014). Schools in education and media hegemony in the perspective of multicultural education. Dalam Proceeding International Conference on Fundamentals and Implementation of Education (ICFIE) 2014 (pp. 191-196). Yogyakarta State University, Yogyakarta.

Dwiningrum, S. I. A. (2015). Modal sosial dalam pengembangan pendidikan:Teori dan praktik. Yogyakarta: UNY Press.

Hasbullah, J. (2006). Social capital: Menuju keunggulan budaya manusia Indonesia. Jakarta: MR-United Press.

Häuberer, J. (2011). Social capital theory. Towards a methodological foundation 
(11 $1^{\text {th }}$ ed.). Wiesbaden: VS Verlag für Sozialwissenschaften.

Matsuura, S., \& Shaw, R. (2015). Exploring the possibilities of school-based recovery and community building in Toni District, Kamaishi. Natural Hazards, 75(1), 613-633. doi: 10.1007/ s11069-014-1344-8.

Ophiyandri, T., Amaratunga, D., Pathirage, C., \& Keraminiyage, K. (2013). Critical success factors for community-based post-disaster housing reconstruction projects in the pre-construction stage in Indonesia. International Journal of Disaster Resilience in the Built Environment, 4(2), 236-249. doi: 10.1108/IJDRBE-03-2013-0005.
Sudaryono. (2006). Pendidikan pasca gempa. Makalah Pelatihan Manajemen Pendidikan Dasar. Diknas DIY, Yogyakarta.

Sudaryono. (2007). Resiliensi dan locus of control guru dan staf sekolah pasca gempa. Jurnal Kependidikan, 37(1), 55-70.

Shrestha, H. D., Yatabe, R., Bhandary, N. P., \& Subedi, J. (2012). Vulnerability assessment and retrofitting of existing school buildings: A case study of Aceh. International Journal of Disaster Resilience in the Built Environment, 3, 52-65. doi: 10.1108/17595901211201132. 